\title{
Chemical and Spectroscopical Characterization of Humic Acids from two South Brazilian Coals of Different Ranks
}

\author{
Deborah P. Dick ${ }^{* a}$, Antonio S. Mangrich ${ }^{b}$, Sonia M. C. Menezes ${ }^{c}$ and Betania F. Pereira $^{b}$ \\ ${ }^{a}$ Instituto de Química, UFRGS, Av. Bento Goncalves, 9500, 91501-970, Porto Alegre - RS, Brazil \\ ${ }^{b}$ Departamento de Química, Centro Politécnico, UFPR, CP 19081, 81531-970, Curitiba - PR, Brazil \\ ${ }^{c}$ Petrobrás, CENPES, Ilha do Fundão - Quadra 7 - Cidade Universitária, 21949-900, Rio de Janeiro - RJ, Brazil
}

\begin{abstract}
Ácidos húmicos (HA) extraídos de carvões de diferentes ranks, de suas amostras regeneradas e de uma amostra nitrada, foram caracterizados por análise elementar e por espectroscopia de infravermelho (FTIR), de ressonância magnética nuclear de ${ }^{13} \mathrm{C}$ no estado sólido (NMR) e de ressonância paramagnética eletrônica (EPR). O HA de carvão de baixo rank apresentou maiores valores de teor de $\mathrm{C}$ e razão $\mathrm{C} / \mathrm{N}$ e menores valores de teor de $\mathrm{O}$ e razões $\mathrm{H} / \mathrm{C}$ e $\mathrm{O} / \mathrm{C}$ do que o de alto rank. Resultados de RMN mostraram que ambas amostras foram mais aromáticas e menos carboxílicas do que HA comuns em solos. Estas características podem limitar o uso de HA de carvão como condicionadores e fertilizantes adequados para solos. A regeneração não provocou alterações relevantes, exceto pelo decréscimo no teor de radicias livres determinados por espectroscopia de EPR. Provavelmente as condições e o tempo de regeneração não foram adequados para oxidar as amostras. Os espectros de FTIR obtidos foram semelhantes, excentuando-se aquele da amostra nitrada, onde a banda de absorção em $1533 \mathrm{~cm}^{-1}$ comprova a presença de grupos nitrogenados. A nitração aumentou o teor de $\mathrm{N}$ e reduziu a razão $\mathrm{C} / \mathrm{N}$ a valores comparáveis aos observados em HA de solos, porém a aromaticidade permaneceu alta e o teor de carboxílicos diminuiu após o processo.
\end{abstract}

Humic acids (HA) extracted from two coals of different ranks, from their regenerated samples and from a nitrated sample, were characterized by elemental analysis and by infra-red (FTIR), solid state ${ }^{13} \mathrm{C}$ nuclear magnetic resonance (NMR) and eletronic paramagnetic resonance (EPR) spectroscopies. The low rank coal HA presented higher $\mathrm{C}$ and lower $\mathrm{O}$ contents, higher $\mathrm{C} / \mathrm{N}$ and lower $\mathrm{H} / \mathrm{C}$ and $\mathrm{O} / \mathrm{C}$ ratios than high rank coal $\mathrm{HA}$. NMR results showed that both samples were more aromatic and less carboxylic than common soil HA. Those characteristics may limit the coal HA efficiency as an appropriate soil conditioner and fertilizer. The regeneration process did not produce major alterations in the coal HA, except a decrease of the free radical content as determined by EPR spectroscopy. Probably, the regeneration conditions and time were not adequate to oxidize the samples. The obtained FTIR spectra were much alike, except that from the nitrated sample, where the absorption band at $1533 \mathrm{~cm}^{-1}$ confirms the presence of nitrated groups. The nitration process increased the $\mathrm{N}$ content and reduced the $\mathrm{C} / \mathrm{N}$ ratio to values comparable to those reported for soil HA, but the aromaticity still remained high and the carboxylic content was lowered after the procedure.

Keywords: humic substances, CP/MAS-NMR, MAS-NMR, FTIR, EPR, coal regeneration, aromaticity, free radicals, coal nitrification

\section{Introduction}

The soil organic matter has a vital role in maintaining soil quality. ${ }^{1}$ The application of organic matter in degraded soils is agronomically very important because it restores soil fertility, improves soil aggregation and hinders soil

* e-mail: dpdick@hotmail.com erosion, among other effects., ${ }^{2,3}$ Amendments to soils of composted organic matter from different sources, like animal manure and sewage sludges, is ecologically very attractive since it also provides an useful fate for those residues. ${ }^{4,5,6}$ Another promising alternative for the use and recycling of non-pedological humic substances is its use in hydroponic solutions to produce plantules under controlled conditions. ${ }^{7}$ 
Humic acids (HA) occur naturally in immature coals and can be easily extracted with alkaline solution. ${ }^{8,9}$ On the other hand, the amount of extractable HA in mature coals, like bituminous coals, is lower. ${ }^{9,10}$ As the coal rank increases, i.e. coal matures, the carbon content gradually increases (from about 700 g.kg-1 in low rank coals to about 950 g. $\mathrm{kg}^{-1}$ in high rank coals) with a corresponding decrease in the oxygen content. ${ }^{9}$ This behavior has also been observed in the respective HA. Additionally, an increase in the aromaticity degree of HA with the coal rank is also reported. ${ }^{9}$ In comparison to soil HA, coal HA contain in general a higher content of $\mathrm{C}$ and lower contents of $\mathrm{O}$ and $\mathrm{N} .{ }^{11,12}$ The reactions of humic substances are determined by their chemical composition and molecular structure ${ }^{1}$ and the quantity and quality of HA in the sample may influence the significance of coal as a soil fertilizer. ${ }^{13-15}$ However, the amount of HA in coals can be increased by oxidizing the sample, ${ }^{3,16}$ resulting what is called "reversed/regenerated coal". Regeneration can be achieved by employing oxidizing agents like oxygen, nitric acid, alkaline permanganate and hydrogen hydroxide, or by exposing the coal sample to the atmospheric oxygen at the earth surface for a larger period, what also leads to the formation of weathered/regenerated coals. ${ }^{9}$ The addition of humic substances extracted from an oxidized coal to a loamy soil and to a sandy-loamy soil was able to retard the onset of the runoff process under rainfall and a significant reduction of soil loss was also observed. ${ }^{15}$ Furthermore, an increase of soil cation exchange capacity, $\mathrm{pH}$ and organic matter was verified after the incorporation of coal derived humic acids in two Nigerian low-fertile tropical soils. ${ }^{17}$ These improvements reflected in a higher crop productivity and showed that the coal humic substances are potentially good soil conditioners.

The main objectives of this study are: (1) to characterize HA from different coal samples through appropriate chemical and spectroscopic techniques (e.g., elemental analysis, FTIR, solid state ${ }^{13} \mathrm{C}$-NMR, EPR); (2) to evaluate the influence of the coal rank, of the regeneration and nitration processes on their chemical structure and composition.

\section{Experimental}

\section{Coal samples}

The studied coal samples, collected by bulk sampling, were as following: a high rank coal from Cambuí Mine, Figueiras, Paraná State, Brazil (HI); a regenerated high rank coal from a 10 years old pile from Cambuí Mine (HR); a low rank coal from Seival Mine, Candiota, Rio Grande do Sul State, Brazil (LO); a regenerated low rank coal from a 15 years old pile from Seival Mine (LR). The fifth studied sample (LN) was obtained by nitrating the sample $\mathrm{LO}$ with concentrated $\mathrm{HNO}_{3}$ at room temperature (soil:solution ratio 8:2). The coal samples were dried at $40{ }^{\circ} \mathrm{C}$, grounded in a quartz mortar and kept in plastic flasks at $4{ }^{\circ} \mathrm{C}$ to prevent oxidation.

\section{Humic acids isolation}

The humic acid extraction was based on Swift. ${ }^{18}$ The coal sample $(0.1 \mathrm{~g})$ was shaken during $2 \mathrm{~h}$ with $30 \mathrm{~mL}$ of $0.1 \mathrm{~mol}$. $\mathrm{L}^{-1} \mathrm{HCl}$; the acid supernatant was separated by centrifugation (10 minutes, $2000 \mathrm{rpm}$ ) and discarded. This procedure was repeated three times. After the acidic pretreatment, the samples were extracted with $30 \mathrm{~mL}$ of 0.5 mol. $\mathrm{L}^{-1} \mathrm{NaOH}$ under mechanical shaking during $3 \mathrm{~h}$. The alkaline extract was separated by centrifugation and stored in a polyethylene flask. This procedure was performed three times. The HA was separated by precipitation with 0.1 mol. $\mathrm{L}^{-1} \mathrm{HCl}$ added to the extract until $\mathrm{pH} 2$ was reached. After $24 \mathrm{~h}$, the precipitated HA was separated from the fulvic acid (FA) by centrifugation and purified by treating the sample with $5 \% \mathrm{HCl} / \mathrm{HF}$ (1:1) solution for $2 \mathrm{~h}$ under mechanical shaking (three times). The purified HA was washed three times with distilled water, frozen overnight, and dried at $60{ }^{\circ} \mathrm{C}$ in vacuum oven. The dried samples were maintained in a dissiccator with silica gel before further analysis. For all coal samples, the fulvic acid fraction was of such low yield as to be ignorable (FA content $<0.01 \%$ of total humic substances).

\section{Elemental analysis}

The HA elemental composition was determined by a Perkin Elmer 2400 elemental analyzer and the content of $\mathrm{O}$ was calculated by difference of $1000 \mathrm{mg} \cdot \mathrm{g}^{-1}$ after correcting the $\mathrm{C}, \mathrm{H}$ and $\mathrm{N}$ values for an ash-free basis. The ash content was obtained gravimetrically after calcinating the HA sample at $750{ }^{\circ} \mathrm{C}$ for $4 \mathrm{~h}$.

\section{Infrared Spectroscopy}

Fourier transform infrared (FTIR) spectra of pellets samples (100 mg KBr and $1 \mathrm{mg} \mathrm{HA}$ ) were recorded on a Win-Bomem \& Michaelson spectrometer on a spectral range of 4000 to $400 \mathrm{~cm}^{-1}$, employing a resolution of $4 \mathrm{~cm}^{-1}, 32$ scans and 21 scans. $\mathrm{min}^{-1}$. The band assignments were made according to Mangrich et al. ${ }^{6}{ }^{6}$ Baranciková et al. ${ }^{19}$ and Rivero et al. ${ }^{19}$ 


\section{${ }^{13}$ C Nuclear Magnetic Resonance}

The solid state ${ }^{13} \mathrm{C}$-NMR spectra were obtained on a Varian INOVA-300 spectrometer (VT CP/MAS probe). Two experimental techniques were tested: (1) single pulsemagic angle spinning technique (MAS), (2) cross polarization with magic angle spinning technique $(\mathrm{CP} /$ MAS). The following experimental conditions were employed: (1) ${ }^{13} \mathrm{C}$-MAS: a resonance frequency of $75.4 \mathrm{MHz}, \mathrm{a} 90^{\circ}$ pulse width, a pulse delay of $100 \mathrm{~s}, 500$ to 900 accumulation transients (corresponding to an overnight acquisition), a $7 \mathrm{~mm}$ silicium nitrate rotor with Kel-F caps and a MAS spinning rate of $5.60 \mathrm{KHz}$; $(2){ }^{13} \mathrm{C}-$ CP/MAS: a resonance frequency of $75.4 \mathrm{MHz}$, a $90^{\circ}$ pulse width, a pulse delay of $2 \mathrm{~s}$, contact time of $500 \mu \mathrm{s}, 3200$ accumulation transients (corresponding to an overnight acquisition), a $7 \mathrm{~mm}$ silicium nitrate rotor with Kel-F caps and a MAS spinning rate of $5.60 \mathrm{KHz} .{ }^{13} \mathrm{C}$ chemical shifts are reported relative to hexa-methylbenzene. Chemical shifts were assigned according to Kögel-Knabner: ${ }^{21}$ alkyl$\mathrm{C}$ from 0 to $65 \mathrm{ppm}$; O-alkyl-C from 65 to $100 \mathrm{ppm}$; aromatic-C from 100 to $165 \mathrm{ppm}$ and carboxylic-C from $165 \mathrm{ppm}$ to $190 \mathrm{ppm}$. The abundance of each carbon type was estimated by integration of the respective spectral region. The region $190 \mathrm{ppm}$ to $230 \mathrm{ppm}$ was not integrated because the MAS rotation was limited to $5600 \mathrm{~Hz}$.

\section{Electron Paramagnetic Resonance}

The EPR spectra were obtained in the solid state at room temperature $(300 \mathrm{~K})$ in quartz tubes. A Bruker ESP $300 \mathrm{E}$ spectrometer was used operating at a frequency of $9.5 \mathrm{GHz}$ (X-band), with a $100 \mathrm{KHz}$ modulation frequency, $2.024 \mathrm{G}$ modulation amplitude and $20 \mathrm{~mW}$ microwave power. HA free radicals were detected and quantified using the approximation: ${ }^{22}$ intensity $\times \Delta \mathrm{H}^{2}$. The areas of the EPR peaks were calibrated with that corresponding to the EPR signal of a "weak pitch" reference of known free radical content obtained from Bruker.

\section{Results and Discussion}

\section{Elemental composition}

The elemental composition and elemental ratios of the humic acids are listed in Table 1. The obtained values for $\mathrm{C}$, $\mathrm{N}, \mathrm{H}$ and $\mathrm{O}$ contents are within the range observed for a diversified group of coal HA's. ${ }^{9}$ The coal HA from the Seival Mine (HA-LO) differed from that from the Cambuí Mine (HA-HI) basically due to the higher $\mathrm{C}$ and lower $\mathrm{O}$ and $\mathrm{N}$ contents, higher $\mathrm{C} / \mathrm{N}$ and lower $\mathrm{O} / \mathrm{C}$ ratios. The increase in the molecular condensation and in the carbon reduction along the coalification development usually reported for bulk coal samples, ${ }^{9,10,11}$ was not verified for the coal humic acids in the present study. It seems that the coal rank did not affect their HA chemical composition. HA with such composition as that verified in the present study are expected to be quite stable with respect to mineralization process. ${ }^{19}$ The $\mathrm{O} / \mathrm{C}$ and $\mathrm{C} / \mathrm{N}$ ratios of samples HA-HI and HA-LO were higher and lower, respectively, than those reported for Australian brown coal HA samples. ${ }^{8} 12$ However, when compared to soil samples, HA-HI and HA-LO presented higher $\mathrm{C}$, lower $\mathrm{N}$ and $\mathrm{O}$ contents than those reported for HA from Brazilian soils ${ }^{23}$ and tropical Venezuelan soils. ${ }^{20}$ On the other hand, similar values for $\mathrm{C}, \mathrm{H}$ and $\mathrm{O}$ contents and for $\mathrm{H} / \mathrm{C}$ and $\mathrm{O} / \mathrm{C}$ ratios observed in the present study have been obtained for HA from Slovakian soils ${ }^{19}$ and from sheep manure. ${ }^{6}$

The chemical composition alterations caused by the regeneration process were different in the two coal samples (Table 1). In the high rank coal HA (HA-HR) a C content increase and an $\mathrm{O}$ content decrease were observed, leading to a lowering of the $\mathrm{O} / \mathrm{C}$ ratio. In the low rank coal $\mathrm{HA}$, a decrease in the $\mathrm{C} / \mathrm{N}$ ratio due to the $\mathrm{N}$ content increase, was observed in the regenerated sample (HA-LR).

Values for $\mathrm{N}$ content and $\mathrm{C} / \mathrm{N}$ ratio comparable to those reported in soil HA, ${ }^{1,19,20,23}$ were successfully obtained by the nitration procedure (Table 1). Nevertheless, the O/C and $\mathrm{H} / \mathrm{C}$ ratios in the nitrated sample (HA-LN) still remained relatively low.

Table 1. Elemental composition, elemental ratios and ash content of the humic acids

\begin{tabular}{lccccc}
\hline Sample & HA-HI & HA-HR & HA-LO & HA-LR & HA-LN \\
\hline $\mathrm{C}^{*}, \mathrm{mg} \cdot \mathrm{g}^{-1}$ & $580 \pm 1.2$ & $640 \pm 1.2$ & $633 \pm 1.9$ & $630 \pm 1.3$ & $588 \pm 0.0$ \\
$\mathrm{H}^{*}, \mathrm{mg} \cdot \mathrm{g}^{-1}$ & $42 \pm 0.6$ & $46 \pm 0.4$ & $44 \pm 0.4$ & $44 \pm 0.4$ & $42 \pm 3.5$ \\
$\mathrm{~N}^{*}, \mathrm{mg} \cdot \mathrm{g}^{-1}$ & $16 \pm 0.0$ & $18 \pm 0.0$ & $12 \pm 0.1$ & $14 \pm 0.0$ & $48 \pm 0.0$ \\
$\mathrm{O}^{* *}, \mathrm{mg} \cdot \mathrm{g}^{-1}$ & $362 \pm 3.2$ & $296 \pm 1.6$ & $312 \pm 2.5$ & $312 \pm 2.5$ & $322 \pm 3.8$ \\
$\mathrm{C} / \mathrm{N}$ & 37 & 36 & 0.86 & 46 & 0.84 \\
$\mathrm{H} / \mathrm{C}^{* * *}$ & 0.88 & 0.35 & 0.37 & 0.37 & 0.86 \\
O/C** & 0.47 & 24.0 & 5.0 & 59.0 & 0.41 \\
Ash, mg.g & 36.0 & & 0.0 & 92.0 \\
\hline
\end{tabular}

* Calculated on an ash-free basis; ** calculated by difference; *** atomic ratios. HA-HI: high rank coal HA, HR: regenerated HA-HI; HA-LO: low rank coal HA; HA-LR: regenerated HA-LO; HA-LN: nitrated HA-LO 


\section{Infrared spectroscopy}

The FTIR spectra of the isolated coal HA are shown in Figure 1. The spectra of the HA-HI and HA-HR samples were very similar and practically no changes due to the regeneration were detected. The most important features of those spectra are: a) a broad band around $3400 \mathrm{~cm}^{-1}$ due to O-H stretching of various groups like phenols and alcohol; b) a couple of peaks at 2922 and $2860 \mathrm{~cm}^{-1}$ and at 1430 and $1334 \mathrm{~cm}^{-1}$ due to $\mathrm{C}-\mathrm{H}$ stretching; c) a well defined band at $1706 \mathrm{~cm}^{-1}$ due to $\mathrm{C}=\mathrm{O}$ stretching of ketonic and carboxylic groups; d) a strong peak at $1615 \mathrm{~cm}^{-1}$ assigned to aromatic $\mathrm{C}=\mathrm{C}$ stretching; e) a broad band around 1250 $\mathrm{cm}^{-1}$ assigned to $\mathrm{C}-\mathrm{O}$ stretching of aryl esters and of $\mathrm{OH}$ deformation of $\mathrm{COOH}$; f) a discrete peak at $1031 \mathrm{~cm}^{-1}$ due to Si-O stretching.

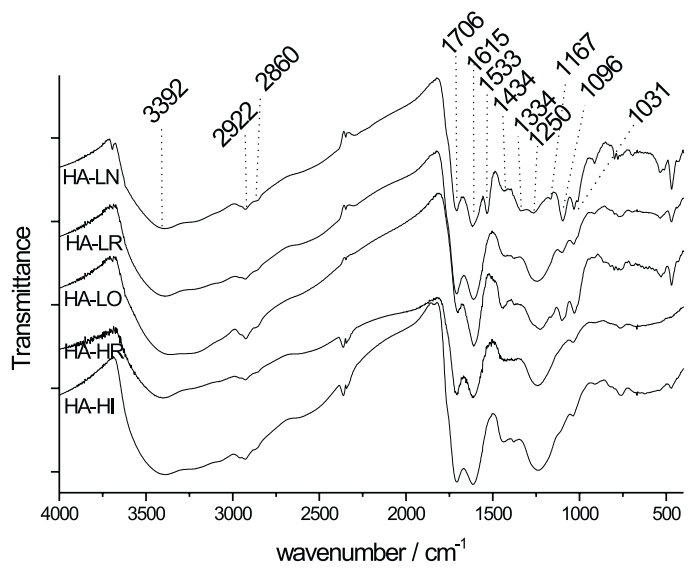

Figure 1. Infrared (FTIR) spectra of the humic acids

Opposite to the HA-HI, HA-HR and HA-LR spectra, the HA-LO sample presented more prominent peaks at 1615 and $1434 \mathrm{~cm}^{-1}$ (Figure 1) attributed to the presence of metal-coordinated carboxylate, which absorbs in this region (antisymmetrical and symmetrical $\mathrm{COO}^{-}$stretching, respectively). This feature is probably more related to the lower effectiveness of the purification process rather than to the regeneration or to the coal rank. Both low rank coal HA samples (HA-LO and HA-LR) showed a well-defined peak at $1096 \mathrm{~cm}^{-1}$ due to $\mathrm{C}-\mathrm{O}$ stretching of ethers and phenols. This absorption band was also observed in the FTIR spectra of an Australian coal HA. ${ }^{10} \mathrm{~A}$ sharp absorption band at $1530 \mathrm{~cm}^{-1}$ due to $\mathrm{NO}_{2}$ stretching observed in the sample HA-LN (Figure 1) is an indicative of the nitration reaction, corroborating the findings from the elemental analysis (Table 1). The intensity decrease of the peak at $1250 \mathrm{~cm}^{-1}$ suggests that nitration occurred at the expenses of the carboxylic groups, while the intensity increase of the band at $1096 \mathrm{~cm}^{-1}$ is probably due to the contribution of the bending of the $\mathrm{C}-\mathrm{N}$ group, that also absorbs in this region. ${ }^{24}$

\section{${ }^{13} C-N M R$ and EPR spectroscopy}

The chemical shifts assignments of the ${ }^{13} \mathrm{C}-\mathrm{NMR}$ spectra and their relative abundance obtained with the MAS and with the CP/MAS technique are given in Table 2. The ${ }^{13} \mathrm{C}$-NMR-MAS spectra are shown in Figure 2.

In comparison to the MAS, the CP/MAS technique intensified the alkyl-C signals and depleted the carboxylic$\mathrm{C}$ and aromatic- $\mathrm{C}$ signals. This cross polarization effect is well reported in the literature and the quantitative interpretation of the ${ }^{13} \mathrm{C}-\mathrm{NMR}-\mathrm{CP} / \mathrm{MAS}$ spectra of soil organic matter and humic substances should be taken with caution. ${ }^{16,21,25}$ Nevertheless, in the present study, the CP/ MAS data showed the same tendency verified with the MAS data, and for comparison purposes between similar samples, the cross polarization technique (which is much faster) is usually considered adequate. ${ }^{16,21,25}$ In the following discussion of functional groups distribution only the NMR-MAS data obtained in this study will be considered.

All five HA presented a much higher aromatic and lower carboxylic contents than those obtained for an Australian brown coal $\mathrm{HA}^{8}$ and those usually reported for soil $\mathrm{HA},{ }^{1,21}$ but are in the range of the values verified for Spanish coal

Table 2. Main resonance regions of the ${ }^{13} \mathrm{C}$-nuclear magnetic resonance spectra and its relative abundance (\%), employing the MAS technique $\left({ }^{13} \mathrm{C}-\mathrm{NMR}-\mathrm{MAS}\right)$ and the CP/MAS technique $\left({ }^{13} \mathrm{C}-\mathrm{NMR}-\mathrm{CP} / \mathrm{MAS}\right)$ of the humic acids

\begin{tabular}{lcccccccc}
\hline HA Sample & \multicolumn{4}{c}{} & \multicolumn{3}{c}{${ }^{13}$ C-NMR-CP/MAS } \\
\cline { 2 - 9 } & Alkyl-C & O-alkyl-C & $\begin{array}{c}\text { Aroma- } \\
\text { tic-C }\end{array}$ & $\begin{array}{c}\text { Carbo- } \\
\text { xylic-C }\end{array}$ & Alkyl-C & $\begin{array}{c}\text { O-alkyl-C } \\
\text { Aroma- } \\
\text { tic-C }\end{array} \begin{array}{c}\text { Carbo- } \\
\text { xylic-C }\end{array}$ \\
\hline HA- HI & 13.9 & 2.7 & 75.8 & 7.6 & 32.5 & 1.0 & 63.7 & 2.8 \\
HA-HR & 10.3 & 3.5 & 78.3 & 7.9 & 24.2 & 1,1 & 72.4 & 2.3 \\
HA-LO & 9.5 & 6.1 & 77.3 & 7.1 & 19.2 & 9.0 & 69.7 & 2.1 \\
HA-LR & 10.3 & 6.1 & 76.3 & 7.3 & 24.4 & 3.7 & 69.4 & 2.5 \\
HA-LN & 14.7 & 3.3 & 80.2 & 1.8 & 34.8 & 1.7 & 62.1 & 1.4 \\
\hline
\end{tabular}

Legend: see Table 1 


\section{HA-LN}
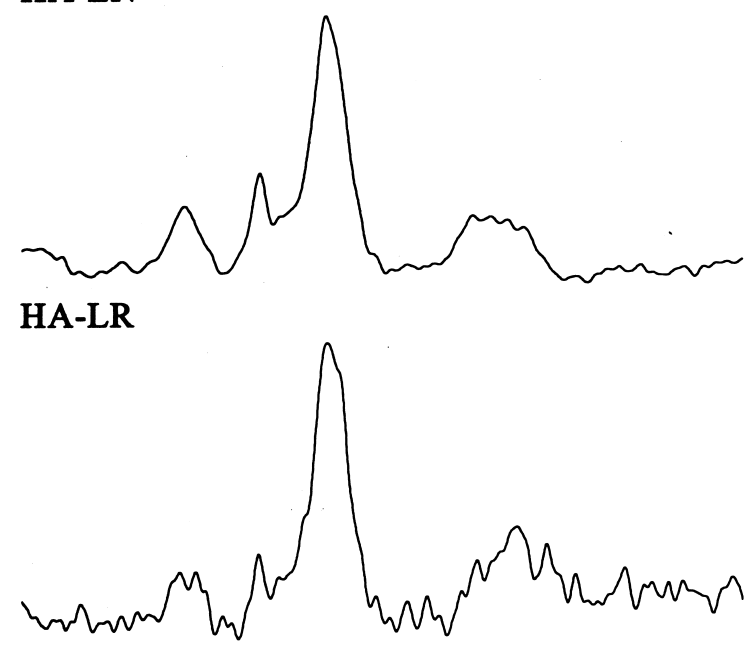

HA-LO

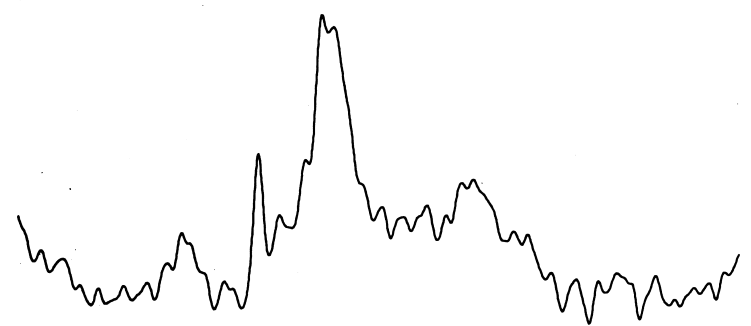

HA-HR

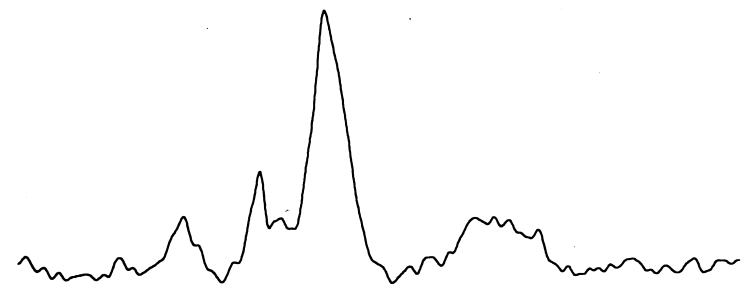

HA-HI

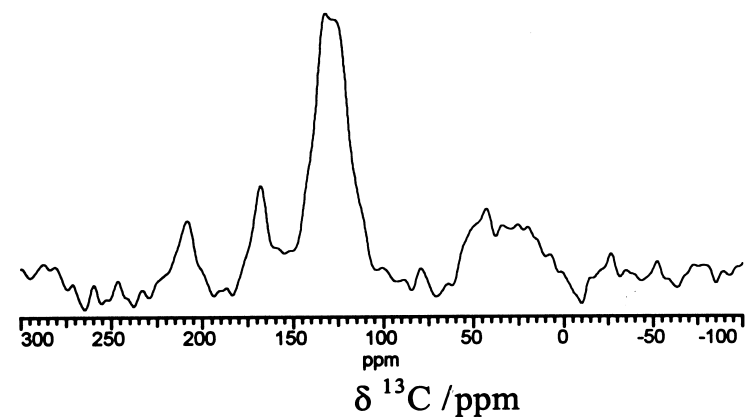

Figure 2. ${ }^{13} \mathrm{C}$ - nuclear magnetic resonance spectra $\left({ }^{13} \mathrm{C}-\mathrm{NMR}-\mathrm{MAS}\right)$ of the humic acids

HA. ${ }^{10}$ In the low rank samples (HA-LO and HA-LR) the abundance of O-alkyl-C groups was greater than that in the high rank coal HA, and this is consistent with the results from the FTIR analysis. This result may be associated to the preservation of carbohydrate-like structures in the low rank coal HA. Analogous to the infrared spectroscopy, no changes in the chemical composition and structure of the humic acids due to coal regeneration in pile were evidenced by the NMR data. On the contrary, the nitration process of the low rank coal HA (HA-LR), produced an increase of the alkyl-C and of the aromatic- $\mathrm{C}$, and a significant decrease of the carboxylic $\mathrm{C}=\mathrm{O}$ and $\mathrm{CH}_{n}-\mathrm{O}$ groups.

The concentrations of free radicals as determined by EPR analysis were similar in the low and in the high rank coal HA (HA-LO and HA-HI) (Table 3) and higher than in the other HA samples. The values obtained in the HA from fresh coal samples are in the range of those already reported for soil $\mathrm{HA}^{19,20}$ and are indicative of a higher humification degree. ${ }^{26}$ The decrease of the free radical concentration in the sample submitted to regeneration (HA-LR) may be due to semiquinone structures oxidation. The same reaction probably occurred by nitration of the sample, although in a lower extent than in the aged sample. The g-values, a typical EPR parameter for molecular structural study, oscillated between 2.0055 and 2.0058 and the line widths between 4.1 and $5.6 \mathrm{G}$. These g-values are more appropriated for 1,4- than for 1,2-semiquinone structures. ${ }^{27}$

Table 3. Electron paramagnetic resonance (EPR) spectral data of humic acids

\begin{tabular}{lccc}
\hline \multirow{2}{*}{ HA Sample } & \multicolumn{3}{c}{ EPR data } \\
\cline { 2 - 4 } & $\begin{array}{c}\text { Free radical, } \\
\left(\text { spins } \times 10^{-17} \mathrm{~g}^{-1}\right)^{*}\end{array}$ & $\begin{array}{c}\text { Line widths } \\
\text { (Gauss) }\end{array}$ & g-values \\
\hline HA-HI & 8.0 & 5.0 & 2.0056 \\
HA-HR & n.m. & n.m. & n.m \\
HA-LO & 7.8 & 5.6 & 2.0058 \\
HA-LR & 4.1 & 5.2 & 2.0056 \\
HA-LN & 6.7 & 4.1 & 2.0055 \\
\hline
\end{tabular}

n.m. not measured

* Calculated on an ash-free basis. Legend: see Table 1

\section{Conclusions}

The analyzed coal humic acids presented a higher aromatic character, a lower carboxylic content and a lower $\mathrm{C} / \mathrm{N}$ ratio than those usually observed for soil HA. These characteristics may limit the application of those two south Brazilian coals as chelating agents, fertilizer or soil conditioner.

The elemental composition obtained in the low rank HA pointed to more hydrophobic character in this sample when compared to the high rank HA. Those results, though, were not confirmed by the IR, ${ }^{13} \mathrm{C}-\mathrm{NMR}$ and EPR data. It seems that the coal rank did not influence in a great extent the chemical and molecular characteristics of their humic acids. The regeneration process did not cause major 
alterations in the coal HA, except in the free radical content as determined by EPR. The regeneration period and/or condition (in pile) was not sufficient to produce HA with chemical and molecular characteristics similar to those of soil HA. The nitration process achieved to reduce the $\mathrm{C} / \mathrm{N}$ ratio of the $\mathrm{HA}$ to a value comparable to that obtained in soil HA, but the aromaticity still remained high and the carboxylic content was lowered after the procedure.

\section{Acknowledgements}

The authors are grateful to JOSAPAR (RS) for supplying the samples and to $\mathrm{CNPq}$ for the financial support.

\section{References}

1. Stevenson, F. J.; Humus Chemistry. Genesis, Composition, Reactions, John Wiley: New York, 1994.

2. Piccolo, A. In Humic Substances in Terrestrial Ecosystems; Piccolo, A. ed.; Elsevier: Amsterdam, 1996, p 225.

3. Piccolo, A.; Pietramallara, G.; Mbagwu, J.S.C.; Geoderma 1997, 75, 267.

4. Inbar, Y.; Chen, Y.; Hadar, Y.; Soil Sci. Soc. Am. J. 1990, 54,1316 .

5. Rumpel, C.; Knicker, H.; Kögel-Knabner, I.; Skjemstad, J.O.; Hüttl, R.F.; Geoderma 1998, 86, 123.

6. Mangrich, A.S.; Lobo, M.A.; Tanck, C.B.; Wypych, F.; Toledo, E.B.S.; Guimarães, E.; J. Braz. Chem. Soc. 2000, 11, 164.

7. Chen, Y. and Aviad, T. In Humic Substances in Soil and Crop Sciences: Selected Readings; McCarthy, P., Clapp, C. E., Malcolm, R.L., Bloom, P.R. eds.; Am. Soc. Agron., Soil Sci. Soc. Am.: Madison, 1990, p 161.

8. Pang, L.S.K.; Vassalo, A.M.; Wilson, M.A.; Org. Geochem. 1989, 16, 853.

9. Lawson, G.J.; Stewart, D. In Humic Substances II: In Search os Structure; Hayes, M.H.B., McCarthy, P., Malcolm, R.L., Swift, R.S. eds.; John Wiley and Sons: Chichester, USA, 1989, p 641.

10. Ibarra, J.V.; Juan, R.; Fuel 1985, 64, 650.
11. Hatcher, P. G.; Energy and Fuels, 1988, 2, 48.

12. Spark, K. M.; Well, J.D.; Johnson, B.B.; Aust. J. Soil Res. 1997, 35, 89.

13. Ibarra, J.V.; Orduna, P.; Fuel 1986, 65, 1012.

14. Stevenson, F.J.; Chen, Y.; Soil Sci. Soc. Am. J. 1991, 55, 1586.

15. Piccolo, A.; Pietramallara, G.; Bazzofi, P.; Pellegrini, S. In Humic Substances in the Global Environment and Implications on Human Health; Senesi, N. and Miano, T. M. eds.; Elsevier: Amsterdam, 1994, p 683.

16. Wilson, M.A.; NMR Techniques and Applications in Geochemistry and Soil Chemistry, Pergamon Press: Oxford, England, 1987.

17. Mbagwu, J.S.C.; Piccolo, A. In The Role of Humic Substances in the Ecosystems and in the Environmental Protection; Drodz, J., Gonet, S.S., Senesi, N., Weber, J. eds.; Polish Society of Humic Substances: Wroclaw, Poland, 1997, p 921.

18. Swift, R.S. In Methods of Soil Analysis. Part 3. Chemical Methods; Sparks, D. L. ed.; Soil Science Society of America: Madison, USA,1996, p 1001.

19. Baranciková, G.; Senesi, N.; Brunetti, G.; Geoderma 1997, $78,251$.

20. Rivero, C.; Senesi, N.; Paolini, J.; D’Orazio V.D.; Geoderma 1998, 81, 227.

21. Kögel-Knabner, I.; Geoderma 1997, 80, 243.

22. Gonçalves, A.B.; Mangrich, A.S.; Zarbin, A.J.G.; Synthetic Metals 2000, 114, 119.

23. Dick, D.P.; Gomes, J.; Rosinha, P.B.; Rev. Bras. Ci. Solo 1998, $22,603$.

24. Silverstein, R.M.; Bassler, G. C.; Morrill, T.C.; Identificação Espectrofotométrica de Compostos Orgânicos, Editora Guanabara Koogan AS.: Rio de Janeiro, 1994, p 380.

25. Preston, C.M.; Soil Sci. 1996, 161, 144.

26. Senesi, N.; Adv. Soil Sci. 1990, 14, 77.

27. Pedersen, J.A.; CRC Handbook of EPR Spectra from Quinones and Quinols; CRC Press: Boca Raton, Florida, 1985, p 57.

Received: May 2, 2001

Published on the web: January 28, 2002 